\title{
PENGARUH MODEL MAKE A MATCH BERBANTUAN PETA PIKIRAN TERHADAP SIKAP SOSIAL DAN KOMPETENSI PENGETAHUAN IPS
}

\author{
N. W. Nia Wijayanti ${ }^{1}$, I K. Gading ${ }^{2}$, D. P. Parmiti ${ }^{1}$ \\ ${ }^{1}$ Jurusan Pendidikan Dasar'2Jurusan IImu Pendidikan, Psikologi dan Bimbingan, Universitas Pendidikan Ganesha, \\ Singaraja, Indonesia \\ e-mail:wayannia572@gmail.com ${ }^{1}, \underline{i k e t u t . g a d i n g @ u n d i k s h a . a c . i d ² ~}^{2},{\underline{d p}-p a r m i t i @ u n d i k s h a . a c . i d^{\beta}}^{\beta}$
}

\begin{abstract}
Abstrak
Penelitian ini bertujuan untuk mengetahui pengaruh model pembelajaran make a match berbantuan peta pikiran terhadap sikap sosial dan kompetensi pengetahuan IPS siswa kelas IV Sekolah Dasar. Penelitian ini merupakan penelitian eksperimen semu dengan rancangan non-equivalent pretest-posttest control group design. Populasi penelitian ini adalah seluruh siswa kelas IV SD di Gugus III Kecamatan Marga tahun pelajaran 2018/2019. Sampel penelitian diambil menggunakan teknik undian dengan memilih 2 kelas dari 8 kelas anggota populasi. Sampel penelitian ini berjumlah 60 orang siswa yaitu 34 orang siswa kelas IV SD Negeri 2 Kuwum sebagai kelompok eksperimen dan 26 orang siswa kelas IV SD Negeri 3 Marga sebagai kelompok kontrol. Instrumen pengumpulan data dalam penelitian ini adalah kuesioner sikap sosial dan tes kompetensi pengetahuan IPS. Data yang telah dikumpulkan dianalisis dengan uji MANOVA. Hasil uji hipotesis I menunjukkan bahwa $\mathrm{F}=747,557$; sig<0,05. Hasil uji hipotesis II menunjukkan bahwa $\mathrm{F}=$ 101,$540 ;$ sig $<0,05$. Hasil uji hipotesis III menunjukkan bahwa $F=72,168 ;$;ig $<0,05$. Berdasarkan temuan di atas dapat disimpulkan bahwa model pembelajaran make a match berbantuan peta pikiran berpengaruh terhadap sikap sosial dan kompetensi pengetahuan IPS siswa kelas IV SD di Gugus III Kecamatan Marga tahun pelajaran 2018/2019.

Kata kunci: make a match, kompetensi pengetahuan IPS, peta pikiran, sikap sosial
\end{abstract}

This study was aimed to determine the effect of the learning model make a match assisted mind maps of social attitudes and social science competency of fourth-grade elementary school. This research was a quasi-experimental study with a non-equivalent pretest-posttest control group design. The population of this study was grade IV elementary school in Cluster III of Marga Subdistrict, in academic year 2018/2019. The research sample was taken using lottery techniques by selecting 2 classes from 8 classes of population. The sample of this study amounted to 60 students, namely 34 students in grade IV of SD Negeri 2 Kuwum as an experimental group and 26 students in grade IV of SD Negeri 3 Marga as a control group. The instruments of data collection in this study were social attitude questionnaires and social science competency tests. The data analysis technique used is MANOVA. The results of the first hypothesis test show that $F$ $=747,557 ;$ sig $<0,05$. The results of the second hypothesis test show that $F=101,540 ;$ sig<0,05. The results of the third hypothesis test indicate that $F=72,168$; sig< 0,05 . Based on the findings above it can be conclude that the learning model make a match assisted mind map influences the social attitudes and social science competency of fourth-grade elementary school students in Cluster III of Marga Subdistrict, in academic year 2018/2019.

Keywords : make a match, mind map, social attitude, social science competency

\section{Pendahuluan}

Pendidikan memiliki peran yang sangat penting dalam menciptakan sumber daya manusia yang berkualitas. Pendidikan yang berkualitas akan mempengaruhi kemajuan dari berbagai bidang. Hal ini sejalan dengan tujuan pendidikan nasional yang tercantum dalam UU No. 20 Tahun 2003 yang menyatakan bahwa: "Tujuan pendidikan nasional adalah mengembangkan kemampuan dan membentuk watak serta peradaban bangsa yang bermartabat dalam rangka mencerdaskan kehidupan bangsa, bertujuan untuk berkembangnya potensi peserta didik agar menjadi manusia yang beriman dan bertakwa kepada Tuhan Yang Maha Esa, berakhlak mulia, sehat, berilmu, cakap, kreatif, mandiri, dan menjadi warga Negara yang demokratis serta bertanggung jawab".

Sebagaimana telah diamanatkan dalam UU No. 20 Tahun 2003 tersebut diharapkan penyelenggaraan pendidikan dapat mewujudkan proses berkembangnya kualitas pribadi peserta didik sebagai generasi penerus bangsa di masa depan. Untuk mencapai tujuan pendidikan nasional pemerintah telah menyelenggarakan perbaikan-perbaikan peningkatan mutu pendidikan 
pada berbagai jenis dan jenjang. Salah satu upaya yang dilakukan pemerintah untuk meningkatkan mutu pendidikan agar menciptakan sumber daya yang berkualitas adalah dengan memperbaiki kurikulum. Permendikbud Nomor 57 tahun 2014 lampiran 1 (dalam Evie Febrianti, Ganing, dan Putra, 2017) menetapkan Kurikulum pada Sekolah Dasar/Madrasah Ibtidaiya yang telah dilaksanakan sejak tahun ajaran 2013/2014 disebut Kurikulum 2013 Sekolah Dasar/Madrasah Ibtidaiyah. Permendikbud Nomor 57 tahun 2014 lampiran I menyatakan "Kurikulum 2013 bertujuan untuk mempersiapkan manusia Indonesia agar memiliki kemampuan hidup sebagai pribadi dan warga negara yang beriman, produktif, kreatif, inovatif, dan afektif serta mampu berkontribusi pada kehidupan bermasyarakat, berbangsa, bernegara, dan peradaban dunia". Pada kurikulum 2013 siswa dituntut melalui beberapa proses secara aktif mencari, mengolah, mengkonstruksi, dan menerapkan pengetahuan.

Pembelajaran Kurikulum 2013 itu mengintegrasikan semua jenis mata pelajaran ke dalam tema. Di dalam tema yang diintegrasikan terdapat IPS atau IImu Pengetahuan Sosial sebagai salah satu muatan materi yang tercantum dan harus dipelajari oleh siswa. Pada pembelajarannya, IPS bertujuan untuk mengembangkan potensi peserta didik agar peka terhadap masalah sosial yang terjadi di masyarakat, memiliki sikap mental postif terhadap perbaikan segala ketimpangan yang terjadi, dan terampil mengatasi setiap masalah yang terjadi sehari - hari baik yang menimpa dirinya sendiri maupun menimpa masyarakat (Susanto, 2014). Dengan demikian, muatan materi IPS dapat membantu peserta didik memiliki sikap, etika, kepribadian, serta pengetahuan dan keterampilan yang paripurna, yang tidak hanya terampil tangannya saja, tetapi juga lembut hatinya, dan cerdas otaknya serta memiliki rasa peka terhadap masalah sosial yang disekitarnya.

Lasmawan (2016) mengemukakan bahwa IImu Pengetahuan Sosial (IPS) program pendidikan yang mengintegrasikan konsep-konsep ilmu sosial dan humanira untuk tujuan pendidikan (membentuk warga negara yang memiliki kompetensi sosial, baik sebagai pribadi, anggota masyarakat, maupun sebagai warga negara dunia). Dengan pendidikan IPS, siswa diharapkan dapat memperoleh pengetahuan sosial, humaniora, memiliki kepekaan dan kesadaran sosial di lingkungannya, serta memiliki keterampilan dalam mengkaji dan memecahkan masalah sosial dalam kehidupannya sehingga akhirnya diharapkan dapat menjadi warga Negara yang baik dan bertanggungjawab. Program pendidikan IPS ini diupayakan untuk meningkatkan kualitas pendidikan khususnya kualitas sumber daya manusia serta untuk mendukung tercapainya tujuan ideal pendidikan. Seperti yang dikemukakan oleh National council for social studies (NCSS) (dalam Lasmawan, 2016) mengemukakan bahwa tidak ada satupun cabang kurikulum sekolah yang lebih sentral daripada pendidikan IPS. Sayangnya, dilapangan banyak yang beranggapan bahwa muatan materi IPS sulit dan membosankan serta pendidikan IPS itu kurang memiliki kegunaan yang besar bagi siswa dibandingkan pendidikan IPA dan Matematika yang mengkaji bidang pengembangan dalam sains dan teknologi (Susanto, 2014). Dengan adanya anggapan seperti ini mengakibatkan tujuan pendidikan IPS belum tercapai secara optimal.

Berdasarkan hasil wawancara yang dilakukan pada tanggal 7 Januari sampai 8 Januari 2019 di SD Gugus III Kecamatan Marga, diperoleh informasi bahwa 1) antusiasme siswa untuk mengikuti proses pembelajaran masih rendah karena ketika guru menjelaskan materi masih ada siswa yang mengobrol, 2) pada saat proses pembelajaran IPS siswa masih kurang aktif, 3) guru jarang menggunakan model pembelajaran yang menarik minat siswa untuk mengikuti proses pembelajaran, 4) guru jarang memanfaatkan media pembelajaran ataupun jarang membuat media untuk membantu dalam proses pembelajaran. Hal ini mempengaruhi rendahnya hasil belajar IPS, terutama penguasaan kompetensi pengetahuan IPS. Dari hasil pengamatan yang dilakukan, menunjukkan sikap sosial siswa rendah. Hal ini terlihat dari siswa tidak perduli dengan orang yang datang ke sekolah, mereka asyik sendiri tanpa memperdulikan orang yang datang, saat proses pembelajaran siswa masih suka menganggu teman saat guru menjelaskan materi.

Beberapa hasil penelitian juga menemukan kondisi pembelajaran IPS di SD masih rendah. Salah satu penelitian yang dilakukan oleh Parbawa dan Sujana (2018) menunjukkan bahwa kompetensi pengetahuan IPS siswa masih jauh dari yang diharapkan karena kurangnya interaksi antara siswa dan guru, siswa dengan siswa lain, maupun siswa dengan sumber belajarnya sehingga kurang berpartisipasi secara aktif dan masih banyak siswa mendapat nilai rendah diantara nilai mata pelajaran lain.Hal ini juga diperkuat dengan hasil pencatatan dokumen tentang nilai ulangan akhir semester 1 kelas IV SD di Gugus III Kecamatan Marga pada muatan materi IPS 
menunjukkan sebagian besar nilai siswa berada dibawah $\mathrm{KKM}$, sehingga rata-rata KKM yang didapatkan tidak optimal. Hal ini dapat dilihat pada tabel 1.

Tabel 1.

Rata-rata Nilai UAS IPS Siswa Kelas IV

\begin{tabular}{|c|c|c|c|c|c|c|c|}
\hline \multirow[t]{2}{*}{ No } & \multirow[t]{2}{*}{ Nama Sekolah } & \multirow[t]{2}{*}{ KKM } & \multirow{2}{*}{$\begin{array}{l}\text { Jumlah } \\
\text { Siswa }\end{array}$} & \multicolumn{2}{|c|}{$\begin{array}{c}\text { Siswa yang } \\
\text { mencapai KKM }\end{array}$} & \multicolumn{2}{|c|}{ Siswa yang belum mencapai KKM } \\
\hline & & & & Siswa & $(\%)$ & Siswa & (\%) \\
\hline 1 & $\begin{array}{l}\text { SDN } 1 \text { Marga } \\
\text { Dajan Puri }\end{array}$ & 78 & 13 & 5 & 38,47 & 8 & 61,53 \\
\hline 2 & $\begin{array}{l}\text { SDN } 1 \text { Marga } \\
\text { Dauh Puri }\end{array}$ & 75 & 13 & 6 & 46,16 & 7 & 53,84 \\
\hline 3 & SDN 1 Marga & 72 & 17 & 8 & 47,05 & 9 & 52,95 \\
\hline 4 & $\begin{array}{l}\text { SDN } 2 \text { Marga } \\
\text { Dajan Puri }\end{array}$ & 70 & 11 & 4 & 36,37 & 7 & 63,63 \\
\hline 5 & SDN 2 Marga & 74 & 15 & 9 & 60 & 6 & 40 \\
\hline 6 & SDN 3 Marga & 61 & 26 & 11 & 42,3 & 15 & 57,7 \\
\hline 7 & SDN 1 Kuwum & 60 & 11 & 5 & 45,46 & 6 & 54,54 \\
\hline 8 & SDN 2 Kuwum & 70 & 34 & 11 & 32,35 & 23 & 67,65 \\
\hline \multicolumn{2}{|c|}{ Jumlah } & & 140 & 59 & 384,79 & 81 & 451,84 \\
\hline \multicolumn{2}{|c|}{ Rata-rata } & & & & 42,15 & & 57,85 \\
\hline
\end{tabular}

Dari data tersebut dapat dilihat bahwa rata-rata nilai ulangan pada muatan materi IPS siswa kelas IV di Gugus III Kecamatan Marga yang mencapai KKM yaitu 42,15\% dan rata-rata nilai siswa yang belum mencapai KKM yaitu 57,85\%. Berdasarkan pencatatan dokumen tersebut dapat diklasifikasikan bahwa nilai ulangan siswa pada muatan materi IPS masih di bawah rata-rata, sehingga menunjukkan bahwa kompetensi pengetahuan IPS siswa masih rendah.

Berdasarkan pemaparan permasalahan tersebut, dipandang perlu peningkatan kompetensi pengetahuan IPS dan sikap sosial dengan menumbuh - kembangkan kecintaan siswa terhadap mata pelajaran IPS melalui inovasi dalam pelaksanaan pembelajaran agar lebih menarik dan menyenangkan. Salah satu cara untuk meningkatkan kompetensi pengetahuan dan sikap sosial siswa dengan cara menerapkan model pembelajaran yang inovatif dan menyenangkan serta mampu meningkatkan keaktifan siswa yaitu model pembelajaran kooperatif tipe Make $A$ Match. Model pembelajaran kooperatif tipe Make $A$ Match adalah model pembelajaran yang dapat meningkatkan minat serta keaktifan siswa dalam mengikuti proses pembelajaran dan menekankan pada adanya kerjasama, aktivitas serta interaksi antara siswa. Shoimin (2014), menyatakan model Make $A$ Match adalah dimana peserta didik mencari pasangannya sambil belajar mengenai suatu konsep atau topik dalam suasana yang menyenangkan, siswa dituntut untuk berkompetisi dengan mencari pasangannya. Pelaksanaan model Make $A$ Match harus didukung dengan keaktifan siswa untuk bergerak mencari pasangan dengan kartu sesuai jawaban atau pertanyaan dalam kartu tersebut. Dalam pembelajaran model Make A Match, suasana belajar di kelas diciptakan sebagai suasana permainan karena adanya kompetisi diantara siswa untuk memecahkan masalah terkait dengan materi pelajaran dan adanya reward atau penghargaan. Oleh karena itu, guru dapat menerapkan model pembelajaran kooperatif tipe Make $A$ Match ini pada pembelajaran IPS sehingga siswa akan lebih tertarik dan lebih aktif dalam mengikuti kegiatan pembelajaran.

Untuk mengoptimalkan proses pembelajaran serta untuk lebih menarik perhatian siswa dalam belajar, maka penerapan model pembelajaraan kooperatif tipe Make $A$ Match ini dintegrasikan dengan sebuah media pembelajaran. Media pembelajaran yang digunakan dalam pembelajaran ini adalah media peta pikiran. Windura (2016), peta pikiran adalah salah satu teknik mencatat yang mengembangkan gaya belajar visual sehingga memudahkan siswa belajar. Peta pikiran mengajarkan untuk mencatat tidak hanya menggunakan tulisan tetapi juga menggunakan gambar dan warna. Dengan menggunakan media ini dapat membuat siswa lebih bisa memahami 
materi yang dijelaskan guru karena siswa akan mencatat poin - poin penting materi tersebut ke dalam bentuk catatan kreatif seperti peta rute yang mempunyai banyak cabang dan juga bisa dibuat lebih menarik dengan menambahkan warna serta bentuk - bentuk yang menarik perhatian siswa.

Model pembelajaran Make $A$ Match dengan berbantuan media peta pikiran dapat melatih siswa untuk aktif dalam pembelajaran serta menuntun siswa untuk bekerjasama sehingga terjalin interaksi antar sesama siswa. Setelah penelitian ini diharapkan melalui model Make A Match berbantuan media peta pikiran dapat meningkatkan kompetensi pengetahuan IPS dan sikap sosial siswa.

Berdasarkan hal tersebut, maka perlu ditindak lanjuti dengan melakukan sebuah penelitian tentang pengaruh model pembelajaran kooperatif tipe make a match berbantuan media peta pikiran terhadap sikap sosial dan kompetensi pengetahuan ips siswa kelas IV di sekolah dasar.

Tujuan dari penelitian ini adalah untuk mengetahui pengaruh sikap sosial dan kompetensi pengetahuan IPS antara siswa yang dibelajarkan dengan model pembelajaran make a match berbantuan peta pikiran dan siswa yang tidak dibelajarkan dengan model pembelajaran make a match berbantuan peta pikiran.

\section{Metode}

Penelitian ini dirancang untuk mengetahui pengaruh model pembelajaran make a match berbantuan peta pikiran terhadap sikap sosial dan kompetensi pengetahuan IPS siswa kelas IV SD di Gugus III Kecamatan Marga. Penelitian ini merupakan penelitian eksperimen semu. Rancangan eksperimen yang digunakan adalah non-equivalent pretest/posttest control group design.

Populasi dari penelitian ini adalah seluruh kelas IV SD di Gugus III Kecamatan tahun pelajaran 2018/2019. Di gugus III terdapat 8 SD yaitu : SDN 1 Marga Dajan Puri, SDN 2 Marga Dajan Puri, SDN 1 Marga, SDN 2 Marga, SDN 3 Marga, SDN 1 Marga Dauh Puri, SDN 1 Kuwum, SDN 2 Kuwum. Pengambilan sampel dilakukan dengan cara mengundi 2 kelas dari 8 kelas. Untuk mendapatkan kelas yang setara dari segi akademik, maka kedua kelas yang terpilih menjadi sampel penelitian diberikan pre-test. Nilai atau skor dari hasil pre-test yang dilakukan digunakan untuk penyetaraan kedua kelas menggunakan menggunakan ANAVA-A yang dilakukan dengan bantuan SPSS 17.0 for windows dengan signifikansi 5\%. Jika angka signifikansi kurang dari 0,05 maka kelas tersebut tidak setara. Sedangkan jika angka signifikansi lebih besar dari 0,05 maka kelas tersebut setara. Kedua kelas yang terpilih menjadi sampel kemudian diundi kembali untuk menentukan kelas eksperimen dan kelas kontrol. Berdasarkan pengundian yang dilakukan, kelas IV SDN 2 Kuwum sebagai kelas eksperimen dan kelas IV SDN 3 Marga sebagai kelas kontrol. Pada kelas eksperimen diberikan perlakuan berupa model pembelajaran Make a Match berbantuan peta pikiran dan kelas kontrol tidak diberikan perlakuan dalam pembelajarannya atau disesuaikan dengan pembelajaran yang biasa diterapkan.

Pengumpulan data dalam penelitian ini adalah data tentang sikap sosial dan kompetensi pengetahuan IPS siswa kelas IV SD di Gugus III Kecamatan Marga. Untuk mengumpulkan data sikap sosial digunakan kuesioner sikap sosial dan kompetensi pengetahuan IPS digunakan tes pilihan ganda biasa kompetensi pengetahuan IPS. Setelah instrument tersusun selanjutnya dilakukan uji coba instrumen penelitian. Instrumen dibuat berdasarkan kisi-kisi. Selanjutnya instrument tersebut diuji validitasnya. Uji coba instrument yang dilakukan adalah uji validitas isi oleh pakar yang selanjutnya dianalisis dengan uji validitas butir, uji daya beda, uji tingkat kesukaran, dan uji reliabilitas.

Selanjutnya pelaksanaan penelitian dilakukan dengan perlakuan terhadap masing-masing kelompok sampel yakni model pembelajaran Make $A$ Match berbantuan peta pikiran pada kelompok eksperimen dan pembelajaran dan tidak diberikan perlakuan dalam pembelajarannya atau disesuaikan dengan pembelajaran seperti biasa. Setelah diberikan perlakuan, kedua kelompok sampel tersebut diberikan posttest.

Teknik analisis yang digunakan adalah dengan analisis deskriptif dan analisis inferensial. Analisis deskriptif dilakukan dengan menghitung mean, median, modus, dan standar devisiasi. Tinggi rendahnya kualitas variabel-variabel penelitian dapat ditentukan dari skor rata-rata tiap-tiap variabel yang dikonversikan ke dalam kriteria penilaian acuan patokan (PAP) skala lima. Analisis inferensial digunakan untuk menguji hipotesis penelitian. Sebelum pengujian hipotesis dilakukan, terlebih dahulu dilakukan uji prasyarat, yaitu uji normalitas dan uji homogenitas varians. Uji 
normalitas ini dilakukan menggunakan teknik Kolmogorov-smirnov dengan bantuan SPSS 17.0 for windows. Pengujian homogenitas dilakukan dengan bantuan SPSS 17.0 for windows melalui uji Box's $M$ untuk uji homogenitas secara bersama-sama dan dengan uji Levene's untuk uji secara terpisah. Kriteria pengujian data memiliki matriks varians-kovarian yang sama (homogen) jika signifikansi yang dihasilkan dalam uji Box's $M$ dan uji Levene's lebih dari 0,05 dan data tidak berasal dari populasi yang homogen jika signifikansi yang dihasilkan dalam uji Box's $M$ dan uji Levene's kurang dari 0,05 . Setelah data normal dan homogen, selanjutnya dilakukan pengujian hipotesis. Pengujian hipotesis ini dilakukan menggunakan analisis statistic MANOVA dengan bantuan SPSS 17.0 for windows.

\section{Hasil dan Pembahasan}

Hasil analisis deskriptif data pretest dan posttest sikap sosial di kelas eksperimen dan kelas kontrol diperoleh bahwa hasil perhitungan dari pretest sikap sosial dan kompetensi pengetahuan IPS siswa disajikan dalam tabel 2.

Tabel 2.

Perhitungan Pretest Sikap Sosial dan Kompetensi Pengetahuan IPS

\begin{tabular}{|c|c|c|c|c|}
\hline \multirow{2}{*}{ Statistik } & \multicolumn{2}{|c|}{ Pretest Sikap Sosial } & \multicolumn{2}{|c|}{$\begin{array}{c}\text { Pretest Kompetensi Pengetahuan } \\
\text { IPS }\end{array}$} \\
\hline & $\begin{array}{l}\text { Kelas } \\
\text { Eksperimen }\end{array}$ & Kelas Kontrol & $\begin{array}{l}\text { Kelas } \\
\text { Eksperimen }\end{array}$ & Kelas Kontrol \\
\hline $\bar{N}$ & 34 & 26 & 34 & 26 \\
\hline Mean & 88,68 & 88,12 & 11,47 & 11,69 \\
\hline Median & 89 & 88 & 12 & 12 \\
\hline Modus & 90 & 87 & 14 & 13 \\
\hline $\begin{array}{l}\text { Standar } \\
\text { Deviasi }\end{array}$ & 3,062 & 2,421 & 2,465 & 2,205 \\
\hline
\end{tabular}

Berdasarkan hasil konversi dapat dinyatakan bahwa rata-rata hasil pretest kelas eksperimen dan kelas kontrol berada pada kategori cukup dan tidak baik.

Hasil perhitungan dari posttest sikap sosial dan kompetensi pengetahuan IPS siswa disajikan dalam tabel 3.

Tabel 3.

\begin{tabular}{|c|c|c|c|c|}
\hline \multirow{2}{*}{$\begin{array}{l}\text { Hasil Posttest } \\
\text { Sikap Sosial } \\
\text { dan Kompetensi } \\
\text { Pengetahuan } \\
\text { IPSStatistik }\end{array}$} & \multicolumn{2}{|c|}{ Posttest Sikap Sosial } & \multicolumn{2}{|c|}{$\begin{array}{c}\text { Posttest Kompetensi Pengetahuan } \\
\text { IPS }\end{array}$} \\
\hline & Kelas Eksperimen & Kelas Kontrol & $\begin{array}{l}\text { Kelas } \\
\text { Eksperimen }\end{array}$ & Kelas Kontrol \\
\hline $\mathrm{N}$ & 34 & 26 & 34 & 26 \\
\hline Mean & 118,79 & 99,19 & 22,18 & 16,92 \\
\hline Median & 120 & 97 & 22,5 & 16,5 \\
\hline Modus & 122 & 96 & 24 & 15 \\
\hline Standar Deviasi & 7,583 & 7,310 & 2,289 & 2,481 \\
\hline
\end{tabular}

Berdasarkan hasil konversi dapat dinyatakan bahwa rata-rata hasil posttest kelas eksperimen berada pada kategori baik dan kelas kontrol berada pada kategori cukup.

Setelah dilakukan perhitungan statistik deskriptif, selanjutnya dilakukan perhitungan statistik inferensial, yaitu uji normalitas sebaran data dan uji homogenitas varians. Hasil perhitungan uji normalitas sebaran data melalui uji statistik Kolmogorov-Smirnov disajikan dalam tabel 4. 
Tabel 4.

Uji Normalitas Sebaran Data

\begin{tabular}{lllll}
\hline & \multirow{2}{*}{ Kelompok } & \multicolumn{3}{c}{ Kolmogorov-Smirnov } \\
\cline { 3 - 5 } & & Statistic & $d f$ & Sig. \\
\hline Sikap Sosial & Eksperimen & 0,134 & 34 & 0,125 \\
\cline { 2 - 5 } & Kontrol & 0,169 & 26 & 0,055 \\
\hline Kompetensi & Eksperimen & 0,146 & 34 & 0,065 \\
\cline { 2 - 5 } $\begin{array}{l}\text { Pengetahuan } \\
\text { IPS }\end{array}$ & Kontrol & 0,145 & 26 & 0,168 \\
\hline
\end{tabular}

Berdasarkan tabel 4 dinyatakan bahwa sebaran data berdistribusi normal karena angka signifikansinya lebih besar dari 0,05 .

Hasil perhitungan pengujian homogenitas dalam penelitian ini ada dua, yaitu secara terpisah dengan menggunakan uji Levene's secara bersama-sama menggunakan uji Box's M. Ringkasan hasil uji homogenitas dengan uji Levene's disajikan dalam tabel 5.

Tabel 5.

Uji Homogenitas dengan uji Levene's

\begin{tabular}{lcccc}
\hline & Levene Statistic & $d f 1$ & $d f 2$ & Sig. \\
\hline Sikap Sosial & 0,040 & 1 & 58 & 0,842 \\
\hline $\begin{array}{l}\text { Kompetensi } \\
\text { Pengetahuan }\end{array}$ & 0,172 & 1 & 58 & 0,680 \\
IPS & & & & \\
\hline
\end{tabular}

Berdasarkan tabel 5, menunjukkan bahwa angka-angka signifikansi lebih besar dari 0,05. $\mathrm{Hal}$ ini berarti data tersebut dinyatakan homogen. Pengujian homogenitas secara bersama-sama menggunakan uji Box's $M$ yang disajikan dalam tabel 6 .

Tabel 6.

Hasil Uji Homogenitas dengan uji Box's $M$

\begin{tabular}{lr}
\hline Box's $M$ & 2,246 \\
\hline$F$ & 0,720 \\
\hline$d f 1$ & 3 \\
\hline$d f 2$ & 414134,297 \\
\hline Sig. & 0,540 \\
\hline
\end{tabular}

Berdasarkan tabel 6, menunjukkan bahwa angka-angka signifikansi lebih besar dari 0,05. $\mathrm{Hal}$ ini berarti data tersebut dinyatakan homogen. Setelah data dinyatakan berdistribusi normal dan homogen, selanjutnya dilakukan pengujian hipotesis.

Hasil analisis MANOVA menunjukkan bahwa pengujian hipotesis pertama menunjukkan bahwa terdapat pengaruh secara simultan model pembelajaran make a match berbantuan peta pikiran terhadap sikap sosial dan kompetensi pengetahuan IPS siswa kelas IV SD. Hal ini dibuktikan dengan Pillai's Trace, Wilks'Lambda, Hotelling's Trace, dan Roy's Largest Root memiliki angak signifikansi lebih kecil dari pada 0,05 . Selanjutnya, pengujian hipotesis kedua menunjukkan bahwa terdapat pengaruh model pembelajaran make a match berbantuan peta pikiran terhadap sikap sosial siswa kelas IV SD di Gugus III Kecamatan Marga. Hal ini terbukti dari hasil analisis diperoleh nilai $F$ sebesar 101,540 dengan angka signifikansi $0,000 \quad(0,000<0,05)$. Kemudian, pengujian hipotesis ketiga menunjukkan bahwa terdapat pengaruh antara kompetensi 
pengetahuan IPS siswa yang mengikuti pembelajaran make a match berbantuan peta pikiran dengan siswa yang tidak mengikuti pembelajaran make a match berbantuan peta pikiran. Hal ini dibuktikan dari hasil analisis didapatkan nilai $F$ sebesar 72,168 dengan signifikansi 0,000 $(0,000<0,05)$. Berdasarkan hasil analisis tersebut menunjukkan bahwa model pembelajaran make a match berbantuan peta pikiran ini lebih berpengaruh untuk meningkatkan sikap sosial dan kompetensi pengetahuan IPS siswa dibandingkan siswa yang tidak dibelajarkan menggunakan model make a match berbantuan peta pikiran.

Secara umum hasil penelitian ini menunjukkan bahwa (1) terdapat pengaruh secara simultan model pembelajaran make a match berbantuan peta pikiran terhadap sikap sosial dan kompetensi pengetahuan IPS siswa; (2) terdapat pengaruh model pembelajaran make a match berbantuan peta pikiran terhadap sikap sosial siswa; (3) terdapat pengaruh model pembelajaran make a match berbantuan peta pikiran terhadap kompetensi pengetahuan IPS siswa kelas IV SD di Gugus III Kecamatan Marga Tahun Pelajaran 2018/2019.

Model pembelajaran make a match berbantuan peta pikiran menjadikan siswa aktif, antusias, dan membuat suasana menyenangkan saat proses pembelajaran. Siswa terlihat aktif dalam pembelajara terutama pada saar masing-masing siswa mencari pasangan kartu yang sesuai dengan kartu yang mereka pegang. Siswa terlihat senang saat mencari pasangan dan menerima pujian dari guru, sehingga menyebabkan suasana pembelajaran menjadi menyenangkan. Siswa terlihat antusias untuk belajar dan tidak ada siswa yang terlihat bosan mengikuti pembelajaran. Hal ini sejalan dengan pendapat Huda (2014) yang menyatakan bahwa model make a match dapat meningkatkan meningkatkan aktivitas belajar siswa, meningkatkan pemahaman siswa terhadap materi yang dipelajari, efektif untuk melatih keberanian siswa, dan melatih kedisiplinan siswa untuk menghargai waktu belajar.

Di samping itu, tampak bahwa siswa memperoleh pengalaman langsung saat proses pembelajaran. Apabila siswa mendapatkan pengalaman langsung saat proses pembelajaran, maka siswa akan lebih mudah untuk menemukan gaya belajarnya sendiri serta siswa lebih mudah memahami materi yang dijelaskan. Dengan adanya pengalaman langsung ini, interaksi antara siswa dengan guru, siswa dengan siswa akan terlihat jelas. Interaksi yang terjadi ini akan mendorong siswa untuk termotivasi untuk belajar sehingga mempengaruhi terhadap sikap sosial yang muncul saat proses pembelajaran. Jika siswa memiliki sikap sosial yang tinggi, maka ia mampu meningkatkan hasil kompetensi pengetahuan yang diperoleh siswa. Hal ini sejalan dengan pendapat Azwar (2003) yang menyatakan bahwa sikap sosial itu muncul dari pengalaman langsung yang dialami oleh siswa dan sikap sosial siswa tersebut muncul karena adanya interaksi sosial yang dialami oleh individu tersebut. Dengan memperhatikan pendapat Huda (2014) dan Azwar (2003) di atas, apabila pembelajaran sudah terjadi dalam suasana yang menyenangkan dan pada saat pembelajaran siswa terlibat secara langsung maka pembelajaran tersebut menjadi bermakna bagi siswa dan dengan pengalaman langsung yang dimiliki oleh siswa memudahkan siswa untuk memahami materi yang dijelaskan dan mempengaruhi sikap sosial yang dimiliki. Hal ini ini tentunya mempengaruhi terhadap sikap sosial yang terbentuk dan kompetensi pengetahuan siswa menjadi lebih optimal.

Model pembelajaran make a match berbantuan peta pikiran memberikan kesempatan siswa untuk bertanggung jawab akan tugas yang diberikan dan saling bekerjasama dengan temannya untuk menyelesaikan permasalahan. Melalui kegiatan tersebut siswa berusaha untuk menyelesaikan permasalahan yang diberikan dengan mencari pasangan kartu yang sesuai. Ini terlihat pada fase mencari pasangan kartu. Pada fase ini siswa terlihat sikap saling bekerjasama antara siswa dan juga menunjukkan tanggung jawab dalam menyelesaikan permasalahan tersebut. Kegiatan ini tentunya mampu menumbuhkan sikap sosial siswa dan juga mempengaruhi proses pembelajaran serta hasi pembelajaran yang diperoleh siswa. Hal ini dengan pendapat Suatnaya, Suwatra, dan Suarjana (2015) yang menyatakan bahwa model pembelajaran make a match merupakan kegiatan yang menuntut kerjasama siswa untuk saling membantu dalam menyelesaikan persoalan. Dengan adanya sikap kerjasama, siswa memiliki sikap yang lebih baik, sehingga berpengaruh terhadap afektif maupun kognitif siswa.

Adanya penghargaan untuk siswa dapat meningkatkan motivasi siswa untuk belajar. Pembelrian penghargaan atau reward berupa tepuk tangan dan pujian dapat membangkitkan semangat siswa untuk belajar. Dengan adanya semangat siswa untuk belajar akan menjadikan siswa lebih aktif dan antusias untuk belajar, sehingga tujuan pembelajaran yang diharapkan dapat 
tercapai dan hasil belajar siswa dapat meningkat. Dalam pembelajaran make a match penghargaan diberikan kepada siswa yang dapat mencari pasangan kartu yang diperolehnya dengan benar dan tepat waktu. Hal ini sesuai dengan temuan penelitian yang dilakukan Aryani (2016) bahwa pemberian reward dapat membangkitkan, menumbuhkan, dan meningkatkan motivasi belajar siswa untuk mencapai tujuan pembelajaran sehingga hasil belajar siswa dapat meningkat.

Model pembelajaran make a match berbantuan peta pikiran terlihat dapat menumbuhkan minat siswa dalam proses pembelajaran. Melalui peta pikiran siswa memahami materi dengan mudah, karena dalam peta pikiran berisi garis yang berlekuk-lekuk dan menjadi kata kunci dalam materi. Selain itu peta pikiran yang dibuat dengan menggunakan gambar dan warna yang berbeda-beda dapat menarik perhatian siswa untuk belajar. Apabila sudah terjadi ketertarikan dengan proses pembelajaran ini mempengaruhi terhadap hasil pembelajaran yang diperoleh siswa. Dengan penggunaan model make a match berbantuan peta pikiran ini mempengaruhi terhadap hasil yang diperoleh siswa. Hal ini sejalan dengan pendapat Windura (2016), peta pikiran (Mind Mapping) adalah salah satu teknik mencatat yang mengembangkan gaya belajar visual sehingga memudahkan siswa belajar. Sependapat dengan itu, Wardani (dalam Yuliani, Margunayasa, dan Parmiti, 2017) yang menyatakan bahwa peta pikiran adalah cara untuk mempermudah siswa agar memahami konsep-konsep yang dipelajari oleh siswa. Dengan demikian, model make a match berbantuan peta pikiran ini dapat menumbuhkan sikap sosial siswa dan juga meningkatkan kompetensi pengetahuan IPS siswa.

\section{Simpulan}

Berdasarkan analisis dan pembahasan seperti yang telah dipaparkan pada bagian sebelumnya, maka dapat disimpulkan bahwa data penelitian yang telah diujikan sebelum melakukan uji hipotesisi sudah berdistribusi normal dan homogeny. Hasil pengujian hipotesis memperoleh hasil, yaitu hasil pengujian hipotesis pertama menunjukkan bahwa secara simultan terdapat pengaruh model pembelajaran make a match berbantuan peta pikiran terhadap sikap sosial dan kompetensi pengetahuan IPS siswa kelas IV Sekolah Dasar.

Hasil pengujian hipotesis kedua menunjukkan bahwa terdapat pengaruh model pembelajaran make a match berbantuan peta pikiran terhadap sikap sosial siswa kelas IV Sekolah Dasar. Hasil pengujian hipotesis ketiga menunjukkan bahwa terdapat pengaruh model pembelajaran make a match berbantuan peta pikiran terhadap kompetensi pengetahuan IPS siswa kelas IV Sekolah Dasar.

Berdasarkan hasil uji hipotesis tersebut dapat disimpulkan bahwa model pembelajaran Make A Match berbantuan peta pikiran berpengaruh terhadap sikap sosial dan kompetensi pengetahuan IPS siswa kelas IV SD di Gugus III Kecamatan Marga Tahun Pelajaran 2018/2019.

Mengacu pada hasil temuan penelitian ini disarankan kepada siswa supaya memperoleh pengalaman belajar yang lebih bermakna sehingga siswa menjadi lebih menguasai materi, hasil belajar dapat meningkat, dan memiliki sikap yang baik. Di samping itu, guru diharapkan dapat memvariasikan proses pembelajaran yang dilakukan di kelas dengan menerapkan model pembelajaran atau penggunaan media pembelajaran seperti model pembelajaran make a match berbantuan peta pikiran agar mampu mengembangkan kemampuan dan pemahamannya. Kepala sekolah juga diharapkan mampu untuk menyediakan fasilitas dan pemberian pelatihan tentang variasi dalam proses pembelajaran seperti penerapan model pembelajaran atau media pembelajaran guna mendukung proses pembelajaran.

\section{Daftar Rujukan}

Apriyani, Maryanto, dan Nurohman. 2016. "Pengaruh Model Cooperative Tipe Make A Match dalam Pembelajaran IPA Terhadap Keterampilan Sosial dan Hasil Belajar Kognitif Siswa SMP”. Jurnal Pendidikan IImu Pengetahuan Alam. Vol 5. No.9.

Aryani, N..P.D. 2016. "Penerapan Model Pembelajaran Make A Match Berbantuan Media Audiovisual Untuk Meningkatkan Motivasi dan Hasil Belajar IPA Siswa Kelas V Semester II Tahun Ajaran 2015/2016 di SD Negeri 5 Banyuning". e-Journal PGSD Undiksha, Vol. 4, No. 1. 
Azwar, S. 2013. Sikap Manusia Teori dan Pengukurannya. Yogyakarta:Pustaka Pelajar.

Febrianti, N.K.E., N. Nym. Ganing \& M. Putra. 2017. "Pengaruh Model Pembelajaran Role Playing Berbantuan Media Topeng Terhadap Kompetensi Pengetahuan IPS Siswa Kelas V SDN Gugus Tuanku Imam Bonjol Kecamatan Denpasar Barat Tahun Pelajaran 2016/2017". Mimbar PGSD. Vol.5, No.2.

Huda, M. 2014. Model-Model Pengajaran dan Pembelajaran Isu-Isu Metodis dan Paradigmatis. Yogyakarta: Pustaka Pelajar.

Lasmawan. 2016. Pendidikan IPS SD. Singaraja: Mediakom Indonesia Press Bali.

Parbawa, I.G.N.M.A. \& I.W. Sujana. 2018. "Pengaruh Model Pembelajaran Visual Auditory Kinestik dan Motivasi Belajar Terhadap Kompetensi Pengetahuan IPS Siswa Kelas IV". Jurnal IImiah Sekolah Dasar. Vol.2, No.1.

Shoimin, A. 2014. 68 Model Pembelajaran Inovatif dalam Kurikulum 2013. Yogyakarta: Ar-Ruzz Media.

Suantara, W.M., N. Kusmariyatni \& Ig. W. Suwatra. 2017. "Pengaruh Model Pembelajaran Make $A$ Match Berbantuan Media Gambar Terhadap Hasil Belajar IPA Sekolah Dasar". Mimbar PGSD. Vol. 5, No. 2.

Suparta, D.G, I W. Lasmawan \& A.A.I.N. Marhaeni. 2015. "Pengaruh Model Pembelajaran Kooperatif Teknik Make A Match Terhadap Motivasi Belajar dan Hasil Belajar IPS". Jurnal Pendidikan Dasar Indonesia. Vol.5.

Suryani, D.A.P, I W. Sujana \& I.B.G. Surya Abadi. 2017. "Pengaruh Model Pembelajaran Make A Match Berbantuan Media Permainan TTS Terhadap Kompetensi Pengetahuan IPS Siswa Kelas V SD Gugus 1 Dalung". Mimbar PGSD. Vol. 5, No.2.

Susanto, A. 2014. Teori Belajar dan Pembelajaran di Sekolah Dasar. Jakarta: Kencana Prenamedia Group.

Undang-Undang Republik Indonesia No. 20 Tahun 2003 tentang Sistem Pendidikan Nasional, 1990. Jakarta: PT. Arnas Duta Jaya

Windura, S. 2016. Mind Mapping : Langkah Demi Langkah. Jakarta: PT. Elex Media Komputindo.

Yuliani, N.P., G. Margunayasa \& D.P. Parmiti. 2017. "Pengaruh Model Pembelajaran POGIL Berbantuan Peta Pikiran Terhadap Hasil Belajar IPA Siswa Kelas V SD". Jurnal of Education Technology. Vol. 1, No.1. 